\title{
Evaluation of the health benefits of consumption of extruded tannin sorghum with unfermented probiotic milk in individuals with chronic kidney disease
}

\author{
Rita de Cássia Stampini Oliveira Lopes ${ }^{\mathrm{a}}$, Samara Letícia Silva de Lima ${ }^{\mathrm{a}}$, Bárbara Pereira da Silva ${ }^{\mathrm{a}}$, \\ Renata Celi Lopes Toledo ${ }^{a}$, Maria Eliza de Castro Moreira ${ }^{a}$, Pamella Cristine Anunciação ${ }^{a}$, \\ Eduardo Henrique Miranda Walter ${ }^{\mathrm{b}}$, Carlos Wanderlei Piler Carvalho ${ }^{\mathrm{b}}$, \\ Valéria Aparecida Vieira Queiroz ${ }^{c}$, Andréia Queiroz Ribeiro ${ }^{\mathrm{a}}$, Hércia Stampini Duarte Martino, ${ }^{\mathrm{a}, *}$ \\ a Nutrition and Health Department, Federal University of Viçosa, PH Rolfes Avenue, s/n, Viçosa 36570-900, Minas Gerais, Brazil \\ b Embrapa Food Technology, Avenida das Américas, 29501, Guaratiba, 23020-470 Rio de Janeiro, RJ, Brazil \\ ${ }^{\mathrm{c}}$ Embrapa Maize and Sorghum, Rodovia MG 424, Km 65, 35701-970 Sete Lagoas, Minas Gerais, Brazil
}

\section{A R T I C L E I N F O}

\section{Keywords:}

Sorghum bicolor L.

Phenolic compounds

Dietary fiber

Antioxidant capacity

Chronic kidney disease

Probiotic

\begin{abstract}
A B S T R A C T
This study investigated the chemical and nutritional composition of breakfast cereal based on whole sorghum, and the effect of its association with unfermented probiotic milk on the inflammation and oxidative stress of individuals with chronic kidney disease. Extruded sorghum breakfast meal presented higher carbohydrate concentration (approximately 71\%), followed by protein (approximately 11\%) and lipid (approximately $0.4 \%$ ). When compared to extruded maize breakfast meal, it presented higher percentage of dietary fiber ( $p<0.05$ ), and higher content of phenolic compounds and tannin, consequently higher antioxidant activity $(\mathrm{p}<0.05)$. Extruded sorghum breakfast cereal combined with unfermented probiotic milk decreased the C-reactive protein $(\mathrm{p}<0.05)$ and malondialdehyde $(\mathrm{p}<0.05)$ serum levels and increased the total antioxidant capacity and superoxide dismutase $(\mathrm{p}<0.05$ ) in patients with chronic kidney disease. Therefore, the extruded sorghum, source of tannin, anthocyanin, and dietary fiber, when consumed with unfermented probiotic milk alleviates the inflammation and oxidative stress in patients with chronic kidney disease.
\end{abstract}

\section{Introduction}

Sorghum (Sorghum bicolor L.) is a cereal from the Poaceae family and has a chemical composition similar to that of corn. Sorghum is native to the tropical regions of Africa and presents great potential for human consumption as a source of dietary fiber and phenolic compounds such as tannins and anthocyanins (Cardoso, Pinheiro, Martino, \& Pinheiro-Sant'Ana, 2017; Gomes et al., 2017). Sorghum is consumed in the form of whole grain, as flour in recipes or as a morning cereal after subjection to an extrusion process (Anunciação et al., 2016; Khan, Yousif, Johnson, \& Gamlath, 2015). Extrusion is a process that combines high pressure, heat and mechanical force in a short time, causing physical and chemical changes to the food matrix. Although the extrusion process influences the bioactive compounds concentrations, it has been used for the products formulation, such as breakfast cereal, popcorn, breads, pastas, and snacks. Thus, this process may be an effective approach to increase the consumption of sorghum by the population (Chávez, Ascheri, Carvalho, Godoy, \& Pacheco, 2017).

Sorghum cultivars such as BRS 305 with pigmented seed heads comprise condensed tannins at high concentrations, which may contribute to a higher phenolic content and increased antioxidant capacity of the diet by $19 \%$, thereby promoting health benefits (Moraes et al., 2012; Moraes et al., 2017). Varieties of sorghum with tannin as well as varieties of sorghum without tannin (such as black sorghum) contain 3deoxyanthocyanidins, which promote beneficial effects on the body, as an anti-inflammatory and antioxidant activity (Awika, Yang, Browning, \& Faraj, 2009; Burdette et al., 2010). However, the tannin sorghum extruded was used because this type has a high molecular weight and

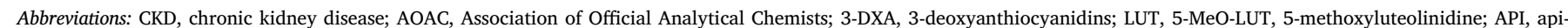

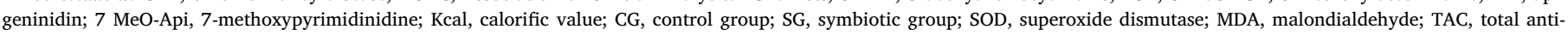
oxidant capacity; CRP, C-reactive protein concentration; IL-6, interleukin 6; IL-10, interleukin 10; TNF- $\alpha$, Tumor necrosis factor $\alpha$

* Corresponding author at: Nutrition and Health Department, Federal University of Viçosa, PH Rolfs Avenue, s/n, Viçosa 36571-900, Minas Gerais, Brazil.

E-mail addresses: hercia72@gmail.com, hercia@ufv.br (H.S.D. Martino).
} 
degree of polymerization. So, when associated with the extrusion process, the tannin sorghum structure changes by the breakdown of polymers into monomers and dimers of proanthocyanidins, contributing to the antioxidant effect and improving the bioavailability of nutrients (Cardoso et al., 2017; Trompette et al., 2014). In addition, the fermentation of the fibers and resistant starch present in sorghum, by anaerobic bacteria increases the concentration of short chain fatty acids in the colonic environment favoring intestinal microbiota balance and intestinal mucosal integrity (Rossi et al., 2016). The modulation of intestinal microbiota can contribute to the reduction in inflammation and oxidative stress of patients with some chronic non-transmissible diseases such as chronic kidney disease (CKD) (Rossi, Klein, Johnson, \& Campbell, 2012).

CKD has become a major public health problem worldwide based on incidence and prevalence rates, which in the past 4 years have grown by around 5\% (Sesso, Lopes, Thomé, Lugon, \& Martins, 2016). The overall mean prevalence of the disease is $13.4 \%$, and is highest in the United States, Canada, Europe and Australia in comparison to countries like India and Africa (Hill et al., 2016). CKD promotes the accumulation of organic residues in the body that interact negatively with various biological functions, accentuating the inflammatory state, oxidative stress, cardiovascular dysfunction and risk of death (Barreto et al., 2014; Lemos, de Alencastro, Konrath, Cargnin, \& Manfro, 2012). To control this accumulation, individuals with CKD need to restrict the intake of some food groups, such as fruits, vegetables and grains, that are sources of micronutrients, dietary fibers, and phytochemicals with antioxidant and anti-inflammatory activity (Riella \& Martins, 2001). Hence, the sorghum can be added to the diet of individuals with CKD to help maintain a balanced nutritional composition, providing fibers, antioxidants, and bioactive compounds. Thus, the consumption of extruded sorghum and probiotic milk may exert a beneficial effect on metabolic control, oxidative stress and inflammation in CKD patients on hemodialysis. Foods with probiotics, which are generally manufactured by the fermentation process, such as fermented dairy drinks, have been used to help control of the oxidative stress in CKD patients (Borges et al., 2017; Odamaki et al., 2012; Ogawa et al., 2012; Taki, Takaiama, \& Niwa, 2005). Another way of producing dairy drinks with probiotics is by directly adding the microorganisms into the food matrix, without the fermentation stage, to preserve milk flavor (Oliveira et al., 2017). However, there is still no scientific evidence that milk and extruded sorghum help in the metabolic control of patients with CKD.

In the present study, we aimed to verify that extruded tannin sorghum breakfast meal is a good source of nutrients for individuals with CKD and that cereal improves inflammation and oxidative stress in these patients when consumed with unfermented probiotic milk.

\section{Material and methods}

\subsection{Cultivating and harvesting the grains}

The grains were cultivated in the experimental field of Embrapa Milho e Sorgo, located in Sete Lagoas, Brazil. The BRS 305 hybrid sorghum with a brown pericarp and tannin was cultivated from April to July 2014, and corn grains with a yellow pericarp were cultivated in the 2013/2014 cropping season. After harvesting, the grains were packed in plastic bags and sent to EMBRAPA Agroindustry of Foods (Rio de Janeiro, Brazil) for processing.

\subsection{Preparation of breakfast cereals}

Sorghum and corn grains were milled in a combined knife-hammer mill TREU (Rio de Janeiro, Brazil) equipped with a sieve size of $1.0 \mathrm{~mm}$ producing fine whole meal flour. Either sorghum or corn flour preconditioned at moisture of $14.0 \%$ was added of $10.0 \%$ refined white sugar (Companhia União de Açúcar, São Paulo, Brazil) and 0.5\% refined $\mathrm{NaCl}$ salt (Ita Serv Sal, Mossoró, Brazil) and processed in a co- rotating twin extruder Evolum HT25 (Clextral Inc., Firminy, France) equipped with a die of four holes of $3.8 \mathrm{~mm}$ each, running at a constant screw speed of $350 \mathrm{rpm}$, feed rate of $10 \mathrm{~kg} / \mathrm{h}$ and temperature profile of 10 heating zones (from feeding to die), as following: $30,60,80,100$, $100,100,110,110,120,120^{\circ} \mathrm{C}$. Low temperature of the feeding region was important to avoid water vapor formation hence allowing a positive flow along the barrel. The combination of temperature of $120^{\circ} \mathrm{C}$ close to the die and screw speed allowed the production of puffed extrudates. A cutter was also installed at the die to produce round shape extrudates. The extrudates were oven-dried at $60^{\circ} \mathrm{C}$ for $2 \mathrm{~h}$, packed in polyethylene bags, and transported by land to the Federal University of Viçosa, where they were stored at $5 \pm 2{ }^{\circ} \mathrm{C}$ until analysis (Fig. S1).

\subsection{Macronutrients, moisture, ash, dietary fiber, resistant starch, and minerals analysis}

For the determination of chemical composition, $15 \mathrm{~g}$ of sorghum and corn extruded flour were used. The determination of ash, protein, lipids, moisture, total dietary fiber and RS was performed according to the methodology proposed by AOAC (2012). The concentration of carbohydrates was calculated by difference. The total energy value of flours was estimated considering the conversion factors of $4 \mathrm{kcal} \cdot \mathrm{g}^{-1}$ for protein or carbohydrate and $9 \mathrm{kcal} \cdot \mathrm{g}^{-1}$ per lipid (Frary \& Johnson, 2005). Calcium, magnesium, copper, iron, zinc, phosphorus, potassium and manganese levels were quantified by atomic absorption spectrophotometry (Gomes, 1996).

\subsection{Total phenolic compounds}

The total phenolic compounds content in sorghum and corn extruded were determined using the Folin - Ciocalteu method (Singleton, Orthofer, \& Lamuela-Raventós, 1999). The extracts were obtained by the addition of $10 \mathrm{~mL}$ of methanol:water (60:40/v:v) solution in $1 \mathrm{~g}$ of the sample. $0.5 \mathrm{~mL}$ of extract was added to $0.5 \mathrm{~mL}$ of Folin - Ciocalteu reagent $(20 \%)$. After homogenization, $0.5 \mathrm{~mL}$ of sodium carbonate (7.5\%) was added. The reaction mixture was homogenized by vortex $(2865 \mathrm{~g}, 10 \mathrm{~s})$ and incubated at room temperature $(30 \mathrm{~min})$. The reading of absorbance was performed in spectrophotometer (Thermo scientific, Evolution 606, USA) at $765 \mathrm{~nm}$. Analytical curve of gallic acid $(0.005-0.10 \mathrm{mg} / \mathrm{mL})$ was used to quantify the compounds $(y=18.66 x+0.084 ; R 2=0.995)$. The results were expressed in $\mathrm{mg}$ of gallic acid equivalents/g of flour (mg GAE/g).

\subsection{Condensed tannins}

Condensed tannin (proanthocyanidins) concentration was determined by the vanillin reaction method (Burns, 1971), with slight modifications (Maxon \& Rooney, 1972; Prince, Van Scoyoc, \& Butler, 1978). In brief, the tannins were extracted by adding $1 \% \mathrm{HCl}$ in methanol in $200 \mathrm{mg}$ of the sample, which was agitated at $0.71 \mathrm{~g}$ for $20 \mathrm{~min}$ at $30^{\circ} \mathrm{C}$. After extraction, the solution was centrifuged at $2790 \mathrm{~g}$ for $20 \mathrm{~min}$, and $1 \mathrm{~mL}$ of the supernatant was mixed with $2.5 \mathrm{~mL}$ of the $1 \%$ vanillin solution in methanol and $2.5 \mathrm{~mL}$ of $8 \% \mathrm{HCl}$ in methanol. After $20 \mathrm{~min}$, absorbance was measured at $500 \mathrm{~nm}$ on a spectrophotometer (Thermo Scientific ${ }^{\circledR}$, model Multiskan Spectrum 1500). The result was obtained by drawing a standard curve for different concentrations of catechin in methanol $(y=0.4343 x+0.0161 ; R 2=0.9984)$ and is expressed in $\mathrm{mg}$ of catechin equivalent per $100 \mathrm{~g}$ of the sample used.

\subsection{Antioxidant activity}

The antioxidant activity of the cereals was determined by performing ELISA. For obtaining the extract, $2 \mathrm{~g}$ of the samples was diluted in $60 \%$ methanol plus $0.1 \mu \mathrm{M}$ methanolic solution of DPPH (1,1-diphenyl-2-picrylhydrazyl) (Blois, 1958). The absorbance was measured at $517 \mathrm{~nm}$ (Thermo Scientific ${ }^{\circledR}$, model Multiskan Spectrum 1500). The 


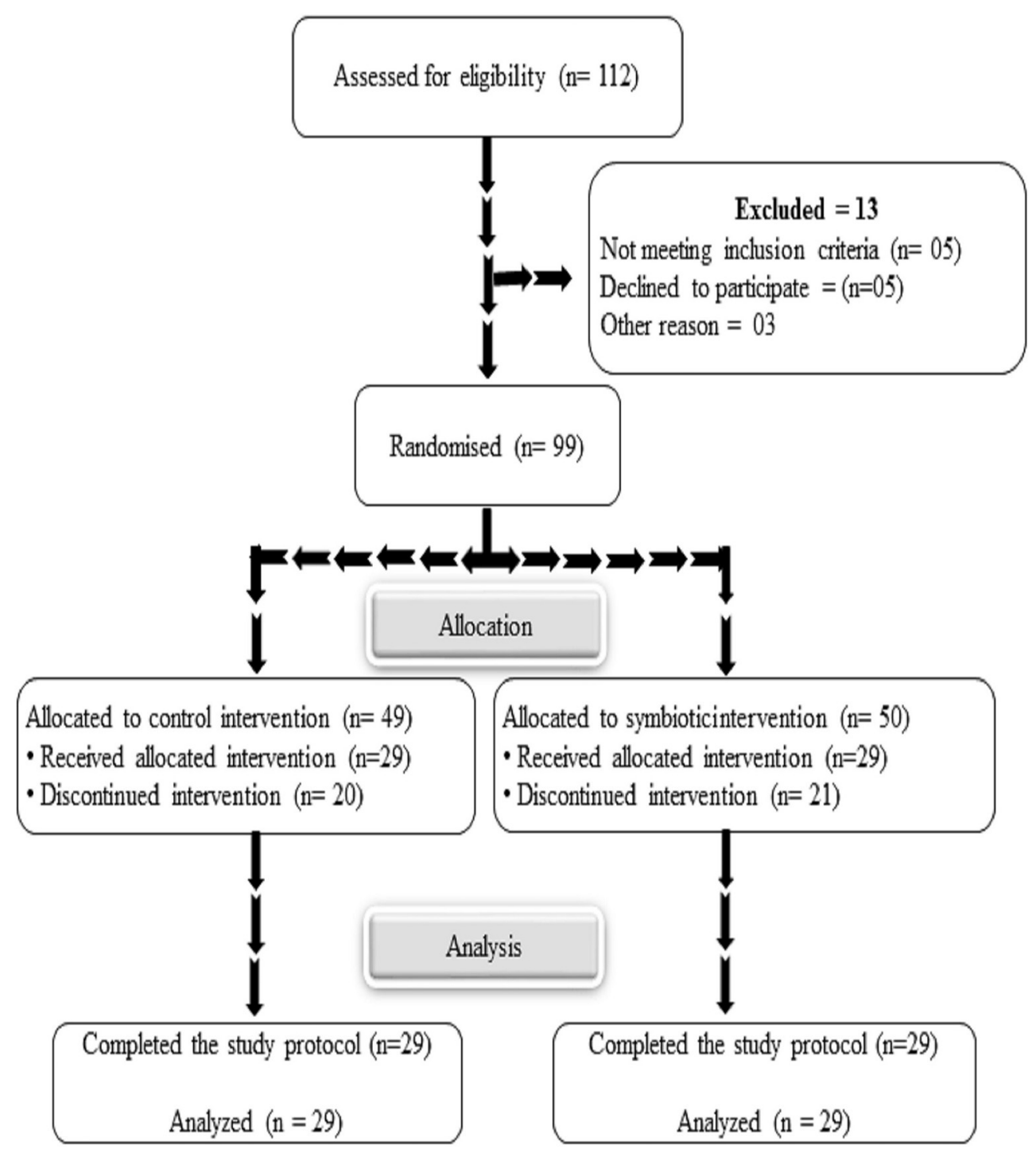

Fig. 1. CONSORT diagram showing the flow of participants through each stage of the trial. CONSORT Consolidated Standards of Reporting Trials.

antiradical activity was expressed in a $\mu \mathrm{mol}$ trolox equivalent/g of the sample $(\mu \mathrm{mol}$ trolox $/ \mathrm{g})$.

\subsection{Flavonoids (3-deoxyanthiocyanidins, flavones, and flavanones)}

The content of flavonoids (3-deoxyanthiocyanidins, flavones, and flavanones) from sorghum was determined in five replicates according to the method described by Yang, Allred, and Geera (2012). For extraction, $2 \mathrm{~g}$ of the sample was added to $20 \mathrm{~mL}$ of methanol:HCl (1:99) and stirred for $120 \mathrm{~min}$. Then, the suspension was centrifuged at $2790 \times g$ for $5 \mathrm{~min}$, the supernatant was collected, packed in an amber bottle, and stored in a freezer $\left(-18 \pm 1{ }^{\circ} \mathrm{C}\right.$ ) (Dykes, Seitz, Rooney, \& Rooney, 2009). The flavonoids were determined by HPLC, and their identification was performed by comparing the retention time and the absorption spectrum of the peaks of the standards and the samples analyzed under the same conditions. For the quantification, analytical curves constructed by injecting standard solutions with six different concentrations in duplicates were used. The $\mathrm{R}^{2}$ of the standard curve ranged from 0.9939 to 0.9999 , detection limits from 18.98 to $35.12 \mathrm{ng}$ / $\mathrm{mL}$, and quantification limits from 94.90 to $175.60 \mathrm{ng} / \mathrm{mL}$. Compounds are expressed as $\mathrm{mg} / \mathrm{g}$ sample, as single compounds, and as the sum of 3-deoxyanthocyanins (3-DXA), flavones, flavanones, and flavonoids.

\subsection{Preparation and viability of milk products}

The dairy drinks used in the study were pasteurized milk, used in the control group (CG) and pasteurized milk with addition of the probiotic bacterium Bifidobacterium longum BL-G301 (Granotec do Brasil S.A.), used in the symbiotic group (SG). The production of the probiotic dairy beverage was carried out weekly in the Federal University of Viçosa, according to the procedures described by Oliveira et al. (2017). The beverages $(100 \mathrm{~mL})$ were packed in a high-density polyethylene plastic bottle with aluminum seal, labeled with date of manufacture, validity, instructions for storage and consumption, and stored under refrigeration at $4 \pm 2{ }^{\circ} \mathrm{C}$ for up to seven days. During the seven weeks of probiotic milk production, samples were collected immediately after preparation and stored under refrigeration at $4{ }^{\circ} \mathrm{C} \pm 2{ }^{\circ} \mathrm{C}$ for seven days to verify the viability of the cells in the final product shelf life. Enumerations of viable Bifidobacterium longum cells were performed by plating on Man Rogosa Sharpe (MRS) agar and incubating in anaerobic at $37^{\circ} \mathrm{C}$ for $72 \mathrm{~h}$ (Ashraf \& Shah, 2011).

\subsection{Intervention}

It is a clinical, randomized, simple blind study, during 7 weeks. The study protocol was approved by the Human Research Ethics Committee 
of the Federal University of Viçosa, number 27364314.8.00005153 and was registered at www.ensaiosclinicos.gov.br under the number RBR2d9ny6. Of the 112 individuals with CKD who underwent hemodialysis in the Nephrology Sector of Hospital São João Batista, in the city of Viçosa, Brazil, 107 were eligible for the study. The participants were older than 18 years and had hemodialysis sections three to four times a week for at least three months. We did not include in the study individuals whose records reported auditory deficiency, with autoimmune disease or with hepatitis B and C virus, with newly implanted catheters, hemodynamic instability, lactose intolerance or milk discomfort. All the selected ones were clarified as to the objectives, methods of the research and the secrecy of the information. Thus, 99 people with CKD accepted to participate in the project and signed the term of free and informed consent. The participants were randomly into two groups: SG ( $100 \mathrm{~mL}$ of dairy drink with probiotic and $40 \mathrm{~g}$ of extruded sorghum flakes) and CG $(100 \mathrm{~mL}$ of pasteurized milk and $40 \mathrm{~g}$ of flakes of extruded corn) and at the end of the intervention there were 58 people included in the study. The reasons why the other 41 did not complete the research were: withdrawal even before the intervention commenced; abdominal discomfort, death, did not fit the food, difficulties in consuming the product at home and hospitalization (Fig. 1). The calculation of the sample size indicated that each group should be composed of 23 patients, considering a difference of $30 \%$ in the concentration of malondialdehyde (MDA), and a statistical power of $90 \%$, after the intervention.

During the hemodialysis, two food kits were given to patients, one which was consumed in the third hour of hemodialysis and another who was consumed on the interdialytic day at home. The patients, who for some reason could not consume the products in the nephrology sector were instructed to take them home and consume them together the same day. Participants during the hemodialysis days were asked about the consumption of the kit and the presence of some adverse effect to verify adherence or not to the study.

\subsection{Data collection}

Socio-demographic and clinical data were obtained before the intervention period, through the collection of information in medical records and through questioners for direct interviews. At the beginning and at the end of the intervention the blood samples were collected by a professional in the nephrology sector and packed in vacuum tubes. The blood was centrifuged and immediately packed in a freezer at $-80^{\circ} \mathrm{C}$.

All anthropometric measurements were performed at the end of the hemodialysis session, after $30 \mathrm{~min}$ of hemodynamic balance. The anthropometric measures included in the study were weight $(\mathrm{kg})$ and height $(\mathrm{cm})$, which were performed according to previously standardized procedures (Jellife, 1968; Lipschitz, 1994; WHO. World Health Organization, 1997).

For the determination of the enzymatic activity of superoxide dismutase (SOD), $30 \mu \mathrm{L}$ of blood serum was added in duplicate in microplates. One hundred eighty-nine microliters of phosphate buffer (50 mM), $6 \mu \mathrm{L}$ of 3-[4,5-dimethyl-thiazol-2-yl]-2,5-diphenyltetrazolium bromide (MTT) and $15 \mu \mathrm{L}$ of pyrogallol were added. The plate was incubated for $5 \mathrm{~min}$ in an oven at $37^{\circ} \mathrm{C}$. After the incubation period, the reaction was stopped by the addition of $150 \mu \mathrm{L}$ of dimethylsulfoxide (DMSO). The plate reading was performed on Elisa reader (Multiskan GO, Thermo Scientific) at $570 \mathrm{~nm}$ and values expressed as U SOD/mg protein.

Dosing of blood MDA was performed in duplicate using the thiobarbituric acid reactive substances (TBARS) method (Buege \& Aust, 1978). The readings were performed in an ELISA apparatus (Multiskan GO, Thermo Scientific) at $535 \mathrm{~nm}$ and the concentration of MDA was determined from the standard curve using standard 1,1,3,3-tetramethoxypropane (TMPO) as standard $\quad\left(\mathrm{y}=4.2904-0.0934 ; \quad \mathrm{R}^{2}=0.9945-\right.$ initial $\quad$ reading; $\mathrm{y}=3339-1.6362, \mathrm{R}^{2}=0.9985-$ final reading). The values were expressed as $\mu \mathrm{mol} / \mathrm{mg}$. The protein concentration used in the calculation of
SOD and MDA activity was measured by the method of Bradford (1976).

Total antioxidant capacity (TAC) was measured by colorimetric assay using the antioxidant assay kit (CS0790, Sigma Aldrich) according to the protocol provided by the manufacturer. The serum antioxidant concentration was measured by spectrophotometry at $750 \mathrm{~nm}$ and was expressed in $\mathrm{mM}$ trolox equivalent from the standard curve $\quad\left(\mathrm{y}=-1.82+1.3213, \quad \mathrm{R}^{2}=0.9976-\right.$ initial $\quad$ reading; $\mathrm{y}=-1.7808+1.3178 ; \mathrm{R}^{2}=0.9942-$ final reading).

Serum concentrations of IL-6, IL-10 and TNF- $\alpha$ were detected by means of the multiple base sandwich immunoassay kit (HCYTOMAG-60K-03, Millipore, Billerica, MA, United States) according to manufacturer instruction. In 96-well plates we added $25 \mu \mathrm{L}$ of serum, which was incubated with antibodies specific for IL-6, IL-10 and TNF- $\alpha$. The fluorescent signal from the beads was detected in the Luminex 200 equipment, xponent/analyst software, version 4.2 and the levels were calculated according to the standard curves that were established by 5 different concentrations $\left(\mathrm{CV}=0 \%, \mathrm{R}^{2}=1\right)$. The C-reactive protein concentration (CRP) was quantified by ultra-sensitive immunoturbidimetry (COBAS-Mira Plus, Roche Diagnostic Systems) using a commercial kit (K079, Bioclin ${ }^{\circledR}$, Minas Gerais, Brazil).

\subsection{Statistical analysis}

The recorded data were reviewed in order to detect missing information and inconsistencies.

The chemical analyses of the extruded cereal were performed in three replicates, except for the flavonoids (five replicates). The normality of the data was evaluated by the Shapiro-Wilk test. The difference between the extruded cereals was evaluated by Student's $t$-test.

The descriptive analysis of the general characteristics of the participants per group was performed. Quantitative variables with normal distribution (according to graphical analysis, asymmetry and kurtosis coefficients and Shapiro-Wilk test) were expressed as mean and standard deviation (SD) and those that did not present normal distribution were expressed in median and minimum and maximum values. Differences between groups were assessed by chi-square test (categorical variables), Student's $t$-test or Mann-Whitney test (numerical variables). Fisher exact-test (categorical variables), paired Student $t$-test or the Wilcoxon test were used to assess differences within the groups. Statistical analysis was performed using the SPSS 20.0 program (SPSS, Inc., Chicago, IL, USA) and the significance level $(\alpha)$ was considered equal to $5 \%$.

\section{Results}

\subsection{Chemical composition of extruded cereals}

3.1.1. Macronutrients, moisture, ash, dietary fiber, resistant starch, and minerals analysis

The extruded sorghum breakfast cereal showed higher content of dietary fiber $(8.84 \%)$, highlights the insoluble fiber, than that showed by extruded corn cereal $(7.28 \%)$ ( $p<0.05)$. A similar content of carbohydrate $(71.04 \%)$ and protein $(11.26 \%)$ was observed in both the extruded cereal. However, extruded corn showed $49 \%$ more lipids ( $\mathrm{p}<0.05)$ and a higher caloric value $(\mathrm{p}<0.05)$ than that showed by extruded sorghum. The resistant starch content of extruded sorghum $(1.03 \pm 0.00)$ was $85 \%$ higher than that found in extruded corn $(0.15 \pm 0.02)(\mathrm{p}<0.05)($ Table 1$)$.

In this study, we observed that the extruded sorghum cereal showed lower phosphorus content $\left(340.33 \pm 2.51 \mathrm{mg} \cdot 100^{-1} \mathrm{~g}\right)$ and higher copper $\left(0.33 \pm 0.01 \mathrm{mg} \cdot 100^{-1} \mathrm{~g}\right)$, zinc $\left(1.93 \pm 0.02 \mathrm{mg} \cdot 100^{-1} \mathrm{~g}\right)$, magnesium $\left(1.45 \pm 0.02 \mathrm{mg} \cdot 100^{-1} \mathrm{~g}\right), \quad$ calcium $\quad(102.00 \pm$ $\left.1.00 \mathrm{mg} \cdot 100^{-1} \mathrm{~g}\right)$, manganese $\left(1.45 \pm 0.02 \mathrm{mg} \cdot 100^{-1} \mathrm{~g}\right)$ and iron $\left(5.59 \pm 0.25 \mathrm{mg} \cdot 100^{-1} \mathrm{~g}\right)$ contents than those showed by extruded corn $(\mathrm{p}<0.05)$. The potassium content in extruded sorghum cereal $\left(353.00 \pm 3.02 \mathrm{mg} \cdot 100^{-1} \mathrm{~g}\right)$ and extruded corn cereal 
Table 1

Nutritional composition of extruded sorghum and extruded corn $\left(\mathrm{g} \cdot 100 \mathrm{~g}^{-1}\right)$.

\begin{tabular}{|c|c|c|}
\hline Variables* & $\operatorname{Mean}^{* *} \pm \mathrm{SD}^{* * *}$ & $\operatorname{Mean}^{* *} \pm \mathrm{SD}^{* * *}$ \\
\hline & Sorghum extruded & Corn extruded \\
\hline Moisture & $6.57 \pm 0.28^{\mathrm{a}}$ & $6.29 \pm 0.31^{\mathrm{a}}$ \\
\hline Ash & $1.87 \pm 0.40^{\mathrm{a}}$ & $1.66 \pm 0.26^{\mathrm{b}}$ \\
\hline Lipids & $0.41 \pm 0.13^{\mathrm{b}}$ & $0.81 \pm 0.91^{\mathrm{a}}$ \\
\hline Protein & $11.26 \pm 1.04^{\mathrm{a}}$ & $12.66 \pm 0.81^{\mathrm{a}}$ \\
\hline Total dietary fiber & $8.84 \pm 0.12^{\mathrm{a}}$ & $7.28 \pm 0.87^{b}$ \\
\hline Soluble fiber & $0.07 \pm 0.55^{\mathrm{b}}$ & $0.87 \pm 0.35^{\mathrm{a}}$ \\
\hline Insoluble fiber & $8.78 \pm 1.70^{\mathrm{a}}$ & $6.41 \pm 0.90^{\mathrm{b}}$ \\
\hline Carbohydrates & $71.04 \pm 0.74^{\mathrm{a}}$ & $71.30 \pm 0.39^{\mathrm{a}}$ \\
\hline Resistant starch & $1.03 \pm 0.00^{\mathrm{a}}$ & $0.15 \pm 0.02^{\mathrm{b}}$ \\
\hline Total energy value $\left(\mathrm{kcal} \cdot 100 \mathrm{~g}^{-1}\right)$ & $332.91 \pm 1.67^{\mathrm{b}}$ & $343.13 \pm 5.16^{\mathrm{a}}$ \\
\hline
\end{tabular}

* Values expressed in dry matter.

** Mean of three replicates.

*** Standard deviation; same letters on the line do not differ by $t$-test for independent samples at $5 \%$ probability.

$\left(353.00 \pm 1.01 \mathrm{mg} \cdot 100^{-1} \mathrm{~g}\right)$ was similar.

\subsubsection{Phenolic compounds and antioxidants}

The extruded sorghum breakfast cereal showed higher content $(\mathrm{p}<0.05)$ of phenolic compounds $(1.10 \pm 0.02 \mathrm{mg}$ galic acid $/ \mathrm{g}$ sample) and condensed tannins (proanthocyanidins) $(0.71 \pm 0.08$ eq.catequina $/ \mathrm{g}$ sample) than that showed by extruded corn cereal $(0.81 \pm 0.01 \mathrm{mg}$ galic acid $/ \mathrm{g}$ sample; $0.00 \pm 0.00$ eq.catequina/g sample, respectively). In addition, the antioxidant activity observed in extruded sorghum cereal $(4.68 \pm 0.01 \mu \mathrm{mol}$ trolox $/ \mathrm{g})$ was higher than that of the extruded corn cereal $(0.68 \pm 0.09 \mu \mathrm{mol}$ trolox/ g) $(\mathrm{p}<0.05)$.

\subsubsection{Flavonoids}

We found two compounds of the 3-DXA group, luteolinidin and 5methoxyluteolinidine, to be present at similar concentrations and detected traces of apigeninidin and 7-methoxyapigeninidine in the extruded sorghum. None of these compounds were found in the extruded corn cereal (Fig. 2A and B). The maximum wavelength and retention time of the 3-DXA group in this study are presented in Fig. 2C. We did not detect flavones and flavonones in either of the cereals.

\subsection{Viability of probiotic milk}

The number of viable Bifidobacterium longum BL-G301 cells concentration in a milk was $9.06 \times 10^{8} \pm 5.4 \times 10^{8} \mathrm{CFU} / 100 \mathrm{~mL}$, with a minimum concentration of $2.5 \times 10^{8} \mathrm{CFU} / 100 \mathrm{~mL}$ and a maximum of $1.5 \times 10^{9} \mathrm{CFU} / 100 \mathrm{~mL}$, indicating the viability of the product during the intervention period.

\subsection{Intervention}

Of the 58 participants who completed the study protocol, the majority were male $(51.7 \%)$. The mean age was $63.1 \pm 10.9$ years and the time of hemodialysis ranged from 3 to 245 months $(55.5 \pm 59.1)$. The level of schooling varied, with the majority having incomplete fundamental education $(56.9 \%)$ and none with higher education. The patients presented diabetes mellitus (44.8\%) and hypertensive nephrosclerosis $(22.4 \%)$ as the main etiologies associated with CKD. Regarding nutritional status before intervention, $19.61 \%$ of CKD patients presented low weight, $52.9 \%$ were eutrophic, and $27.4 \%$ were overweight/ obese. The randomization of the groups was adequate, since they did not present differences in age, BMI, sex, presence of diabetes, and inflammatory or oxidative stress markers ( $p>0.05$ ) (Table 2).

In relation to oxidative stress, we observed that after the intervention, serum MDA decreased ( $p<0.05)$, and SOD and TAC increased ( $\mathrm{p}<0.05$ ) compared to that in CG (Fig. 3A). In addition, we observed that delta values for SOD and TAC in the SG group were higher than those in the CG group (Fig. 3B).

The SG group presented a decreased in serum CRP concentration $(\mathrm{p}<0.05)$ in comparison to the intergroups (Fig. 4A) and showed a decreased in TNF- $\alpha$ concentration $(\mathrm{p}<0.05)$ in relation to delta values (final value - initial value) (Fig. 4B). This group also presented a reduction in IL-10 concentration (Fig. 4c), however, there was no change ( $p$ > 0.05) among IL-6, IL-10 and TNF- $\alpha$ cytokines intergroups (Fig. 4A). The SG presented a moderate negative correlation of SOD values with CRP values $(\mathrm{r}=-0.373, \mathrm{p}<0.05)$ and IL-10 $(\mathrm{r}=-0.387, \mathrm{p}>0.05)$.

\section{Discussion}

This research is the first to investigate the effects of consumption of extruded whole sorghum breakfast cereal and unfermented probiotic dairy beverage on the inflammation and oxidative stress markers in individuals with CKD in hemodialysis. In relation to the chemical composition, the extrusion process promotes the transformation of food and changes its chemical, physical, and nutritional characteristics, as it involves high temperatures, pressures, humidity, and mechanical stress (Cardoso et al., 2017). In our study, the extruded sorghum cereal presented a higher carbohydrate content (approximately 71\%), followed by protein (approximately 11\%) and lipid (approximately $0.4 \%$ ) contents. The extruded sorghum cereal also presented higher content of dietary fiber, phenolic compounds, antioxidant activity, and tannin in relation to extruded corn cereal. When comparing our result with the centesimal composition of whole sorghum flour of the same genotype, we observed a lower carbohydrate concentration (62.09\%) and a higher concentration of lipids (2.60\%) and dietary fiber (11.43\%) (Martino et al., 2012). Llopart, Drago, De Greef, Torres, and González (2013) analyzed the effects of extrusion temperature $\left(164,182\right.$, and $\left.200{ }^{\circ} \mathrm{C}\right)$ on the physicochemical properties of extruded red sorghum, and found a high concentration of dietary fiber (9\%) and a similar percentage of protein $(11 \%)$ and ashes $(1.5 \%)$. Despite the reduction in fiber content promoted by grain processing, extruded sorghum morning cereal continues to be classified as a source of fiber when consumed at a minimum portion of $40 \mathrm{~g}$ ( $3.6 \mathrm{mg}$ of total fiber), in accordance with Brazilian legislation which states that for a food to obtain this denomination, it must provide at least $3 \mathrm{~g}$ of dietary fiber per portion consumed (ANVISA, 2017). In addition, this 40-g portion should provide approximately $12 \%$ of the daily recommended requirement of this nutrient, according to the recommendations of the Institute of Medicine (2002).

In our study, we observed that the extruded sorghum cereal showed lower phosphorus content, similar amounts of potassium, and higher, zinc, magnesium, calcium, manganese, and iron content than those showed by extruded corn. High phosphorus and potassium contents could be a limiting factor for considering extruded sorghum as an ideal meal for patients with CKD. The nutritional recommendations advocate that the foods indicated for patients with CKD should have a potassium content of $<5 \mathrm{mEq}$ or $195 \mathrm{mg}$ per serving (Riella \& Martins, 2001). A portion of $40 \mathrm{~g}$ of extruded sorghum morning cereal (measured as percentage of dietary fiber) has a potassium content of $141 \mathrm{mg}$, and can be indicated for patients with CKD. With respect to the content of zinc $(1.93 \pm 0.25)$ found in extruded sorghum cereal, we propose that it can be used as a zinc food source since zinc-rich foods such as meats and legumes have around 0.99 to $4.0 \mathrm{mg}$ of the mineral per $100 \mathrm{~g}$ of the product (De Andrade, Barros, Mello, \& Takase, 2004). The inclusion of a food source of zinc in the diet could assist in improving the oxidative stress in CKD patient. Zinc can stabilize the structure of SOD, and may be a proton donor during the oxidative cycle of the enzyme (Li, Jiao, 

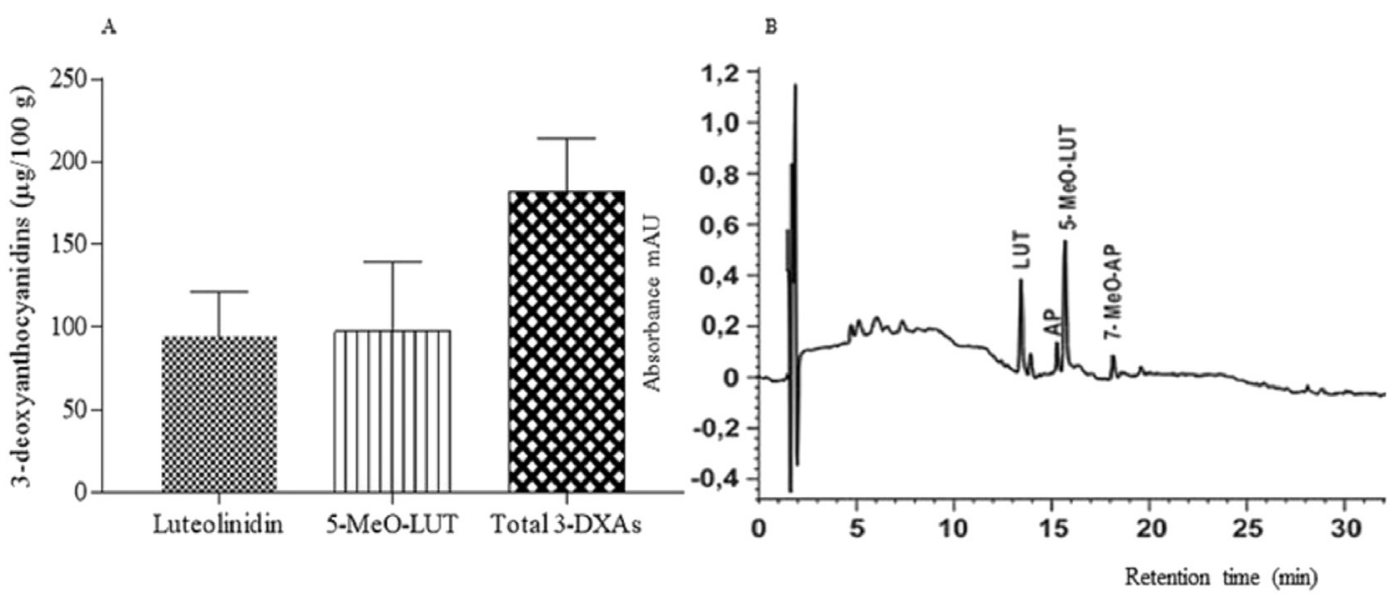

C

\begin{tabular}{|l|c|c|}
\hline Compound & $\lambda$ max (nm) & $\begin{array}{c}\text { Retention time } \\
\text { (min.) }\end{array}$ \\
\hline Luteolinidin & 239 & 13,3 \\
\hline Apigeninidin & 239 & 15,1 \\
\hline 5-methoxyluteolinidine & 239 & 15,5 \\
\hline 7-methoxyapigeninidine & 239 & 17,9 \\
\hline
\end{tabular}

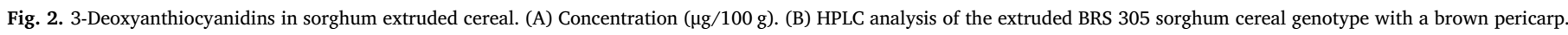

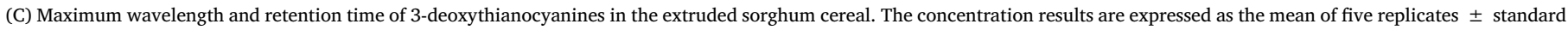
deviation.

Table 2

Baseline characteristics of subjects with chronic kidney disease on hemodialysis according to experimental groups.

\begin{tabular}{|c|c|c|c|}
\hline Variables & $\begin{array}{l}\text { Control group } \\
(\mathrm{n}=29)\end{array}$ & $\begin{array}{l}\text { Symbiotic group } \\
(\mathrm{n}=29)\end{array}$ & $\mathrm{p}$ value \\
\hline Age (years) ${ }^{\mathrm{a}}$ & $63.03 \pm 10.77$ & $63.17 \pm 11.16$ & 0.96 \\
\hline BMI $\left(\mathrm{kg} / \mathrm{m}^{2}\right)^{\mathrm{a}}$ & $23.26 \pm 9.60$ & $24.74 \pm 4.24$ & 0.15 \\
\hline Sex ${ }^{\mathrm{b}}$ & & & 0.17 \\
\hline Male & $21(72.4)$ & $17(58.6)$ & \\
\hline Female & $8(27.6)$ & $12(41.4)$ & \\
\hline Diabetes $^{\mathrm{b}}$ & & & 0.74 \\
\hline Yes & $13(44.8)$ & $13(44.8)$ & \\
\hline No & $16(55.2)$ & $16(55.2)$ & \\
\hline \multicolumn{4}{|l|}{ Inflammatory markers ${ }^{\mathrm{a}}$} \\
\hline $\mathrm{CRP}(\mathrm{mg} / \mathrm{dL})$ & $0.80(0.04 ; 2.86)$ & $0.85(0.01 ; 2.62)$ & 0.99 \\
\hline IL10 (pg/mL) & $0.48(0.12 ; 2.44)$ & $0.44(0.10 ; 3.01)$ & 0.59 \\
\hline IL6 $(\mathrm{pg} / \mathrm{mL})$ & $6.09(1.12 ; 15.43)$ & $4.21(0.98 ; 15.41)$ & 0.22 \\
\hline $\mathrm{TNF} \alpha(\mathrm{pg} / \mathrm{mL})$ & $28.14 \pm 12.45$ & $30.27 \pm 12.53$ & 0.41 \\
\hline \multicolumn{4}{|l|}{ Oxidative stress markers $\mathrm{a}^{\mathrm{a}}$} \\
\hline SOD (U SOD/mg ptn) & $2.21(0.87 ; 7.40)$ & $2.32(1.00 ; 7.77)$ & 0.53 \\
\hline MDA (MDA nmol/g ptn) & $1.03(0.55 ; 4.82)$ & $1.01(0.37 ; 3.28)$ & 0.83 \\
\hline TAC (Mm trolox) & $0.492 \pm 0 ., 104$ & $0.518 \pm 0.097$ & 0.34 \\
\hline
\end{tabular}

${ }^{\mathrm{a}}$ Mean \pm Std. Deviation, Independent Samples t-test; median (minimum; maximum), Mann-Whitney test.

${ }^{\mathrm{b}} \mathrm{n}$ (\%), Pearson Chi-Square Tests. BMI - body mass index; CRP - C-reactive protein; IL10 - Interleukin 10; IL6 - Interleukin 6; TNF $\alpha$ - Tumor necrosis factor $\alpha$; SOD Superoxide dismutase; MDA - malondialdehyde; TAC - Total antioxidant capacity.

Chen, \& Liang, 2010).

The content of phenolic compounds, condensed tannin, and antioxidant activity were higher in the extruded sorghum cereal in comparison with extruded corn cereal. However, when comparing our results with the whole sorghum flour, we observed that the whole flour had a higher content of phenolic compounds and tannins than the extruded sorghum cereal, but a similar antioxidant capacity (Moraes et al., 2012). The decrease in the contents of phenolics and tannins may be due to the extrusion of sorghum grains. The condensed tannins (proanthocyanidins) present in sorghum have a high molecular weight and a high degree of polymerization, and the extrusion process can alter this structure by the breakdown of these polymers into monomers and dimers of proanthocyanidins, which have greater bioavailability and a higher antioxidant effect (Cardoso et al., 2017; Trompette et al., 2014). The presence of the antioxidant effect observed in our study after the extrusion process was also observed in a study comparing the extrusion process of three different sorghum cultivars (Cardoso et al., 2014).

We found all compounds of the 3-DXA group in the extruded sorghum cereal, different from that observed by Anunciação et al. (2017), who found four compounds. The difference between the results can be accounted for by the growth process and the difference in extrusion process conditions. A study on extruded sorghum (SC 319 brown pericarp genotype) showed that extrusion leads to a reduction in the content of these flavonoids, with a mean retention of $29.3 \%$ (Cardoso et al., 2015).

The absence of flavones and flavonones cannot be attributed to the extrusion process because no study describes the stability of these flavonoids in cereals. Moreover, the results of our study are similar to those described by Cardoso et al. (2015) and Anunciação et al. (2016). The authors not detected these compounds in extruded sorghum of SC317 and SC319 genotypes, both with brown pericarp, indicating the sensitivity of these compounds to heat processing. Although our study has shown a loss in the content of anthocyanins probably due to the extrusion process, sorghum cereal can provide health benefits to patients with CKD because the presence of anthocyanins may activate and enhance the antioxidant defense system of the individual (Shih, Yeh, \& Yen, 2007).

The viability of probiotic milk indicated that the concentration of viable Bifidobacterium longum BL-G301 cells $\left(9.06 \times 10^{8}\right.$ $\pm 5.4 \times 10^{8} \mathrm{CFU} / 100 \mathrm{~mL}$ ) was adequate during the intervention period. Some studies have already been published demonstrating the 


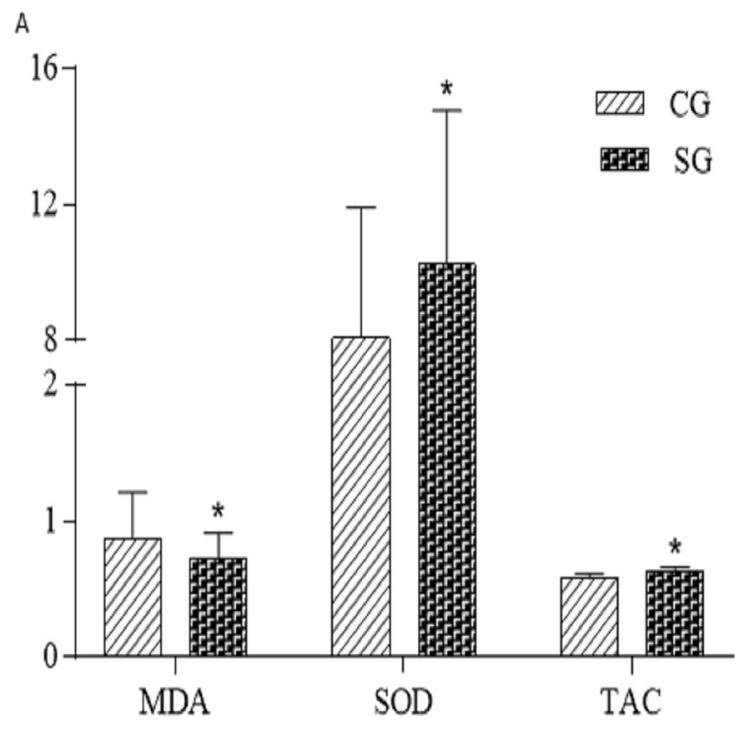

B
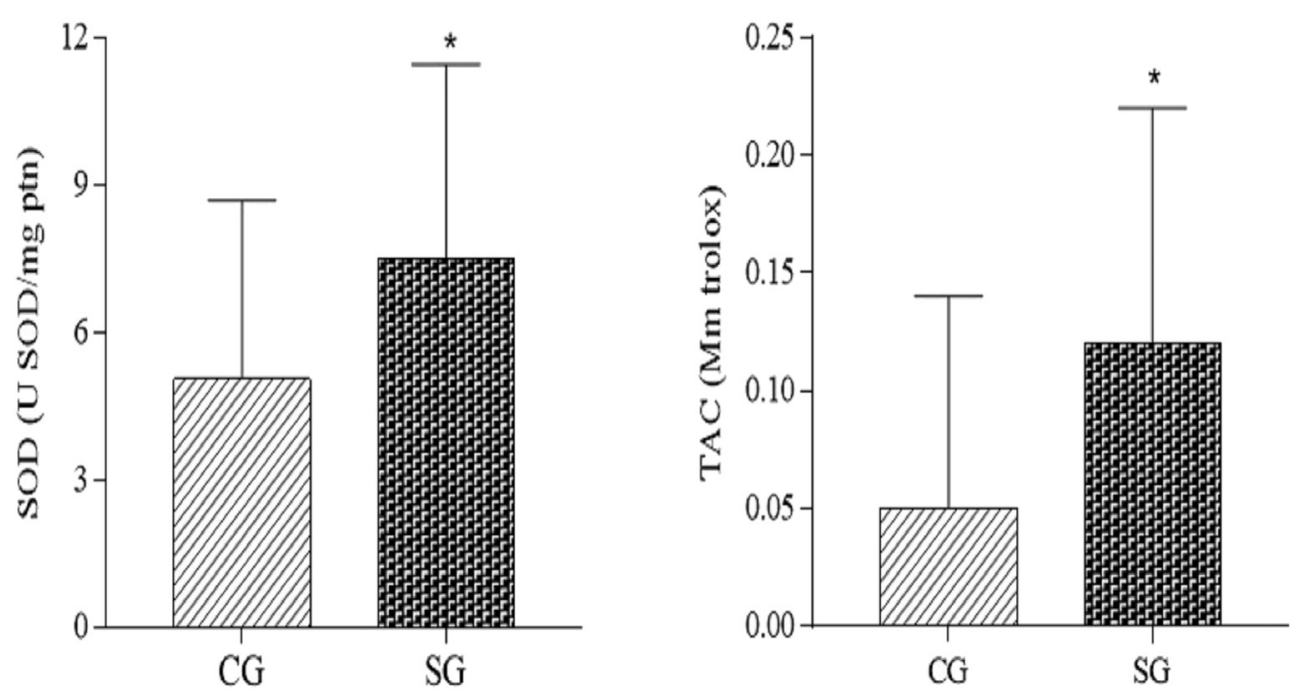

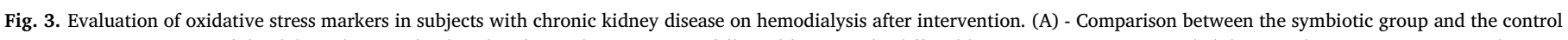

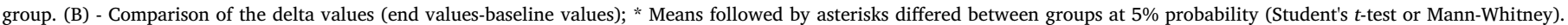

effect of high (Gionchetti et al., 2007) or low probiotic concentrations on human health (Whorwell et al., 2006), although there is no recognized level of cellular concentration that guarantees an effect on health (Reid, 2008).

Oxidative stress in uremia may be associated with an increase in the expression or activity of $\mathrm{NAD}(\mathrm{P}) \mathrm{H}$ oxidase and with the reduction in natural antioxidant factors, leading to the accumulation of reactive oxygen species (Cachofeiro et al., 2008). Patients on hemodialysis presented low blood antioxidant capacity and high oxidative stress degree due to antioxidant losses during dialysis interactions between the blood and the dialysis membrane and malnutrition that decreases food absorption (Cachofeiro et al., 2008; Coombes \& Fassett, 2012).

The symbiotic investigation ( $40 \mathrm{~g}$ of the extruded sorghum cereal and $100 \mathrm{~mL}$ of a dairy beverage with probiotic) of seven weeks of intervention, was able to decrease CRP and MDA levels as well as increase TAC and SOD when compared with that of the control product ( $40 \mathrm{~g}$ of extruded corn flakes and $100 \mathrm{~mL}$ of milk). These results may be associated with tzinc, dietary fiber, tannins, phenolic compounds, and flavonoids contents in the extruded sorghum cereal and the concentration of Bifidobacterium longum present in probiotic milk. The intake of the probiotic milk associated with extruded sorghum that presented a high concentration of dietary fiber and polyphenolics compounds may contribute to changes in the colonic environment and the reduction of oxidative stress in CKD patients. The fiber fermentation by the probiotic can increase the production of short chain fatty acids and decrease the colonic $\mathrm{pH}$, favoring the growth of gram positive bacteria and reducing the presence of lipopolysaccharide, one of the factors responsible for the increase in oxidative stress and inflammation (Kallapura, Pumford, Hernandez-velasco, \& Hargis, 2014).

In our study, the oxidative stress was attenuated after the intake of the extruded sorghum cereal with the probiotic dairy drink, since there was an increase in SOD and TAC in the SG. The high intake of polyphenols compounds from BRS 305 extruded sorghum (condensed tannins: $13.06 \pm 1.52 \mathrm{mg}$ catechin/portion; flavonoids: $76.78 \pm 12.92 \mu \mathrm{g}$ total 3DXAs/portion; phenolic compounds: $44.20 \mathrm{mg}$ of gallic acid/portion) can act directly on the inflammatory process owing to their antioxidant and anti-inflammatory properties, avoiding or decreasing the formation of reactive oxygen species (Cardoso et al., 2017; Castilla et al., 2008). Moreover, the structures of these compounds, which are composed of phenolic rings and hydroxyl groups, act directly on the formation of reactive oxygen species by donating hydrogen or electrons and inhibit the oxidative reactions of biological molecules (Vattem \& Shetty, 2005). Furthermore, they 

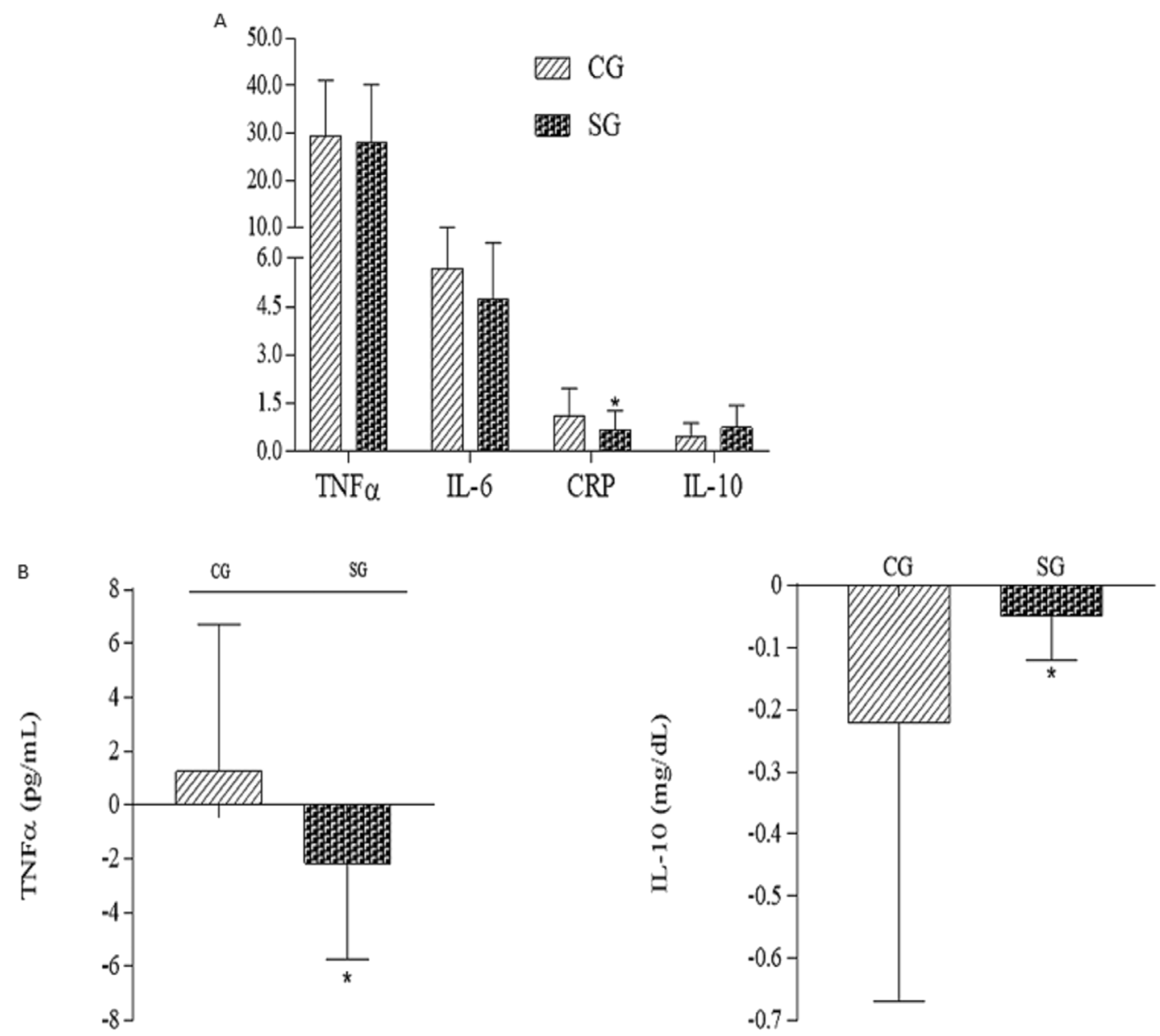

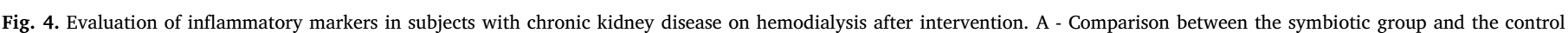
group. B - Comparison of the delta values (end values-baseline values); * Means followed by asterisks differed between groups at $5 \%$ probability (Student's t-test or Mann-Whitney).

can also regulate the biosynthesis of glutathione and enzyme expression which modulate the defense system against oxidative stress by continuously converting highly reactive electrophilic species into non-toxic and excretable metabolites, that can modulate the transcription of factor Nrf2 and prevent the activation of nuclear factor NF-kB (Cardoso et al., 2017; Kim, Cha, \& Surh, 2010; Saldanha et al., 2016) (Fig. 5).

CRP levels have been shown to be a good marker to define this inflammation and the risk of cardiosvascular disease in CKD patients. Its reduction in patients on hemodialysis has been associated with the intake of polyphenols, which have high antioxidant and anti-inflammatory capacity (Seifried, Anderson, Fisher, \& Milner, 2007). In fact, our study demonstrated that supplementation with sorghum breakfast cereal (source of phenolic compounds) with unfermented probiotic milk drink can prevent the progression of inflammation, since the CRP levels in the test group decreased after the intervention. GarcíaMediavilla et al. (2007) showed that flavonoids can modulate CRP expression and induce changes in nuclear factor kappa B (via NF-kB), contributing to the anti-inflammatory effects through mechanisms that may involve blocking the activation of NF- $\mathrm{KB}$ and the resulting increase in the regulation of pro-inflammatory genes (Fig. 5).

In our study, the results can be attributed to the symbiotic effect of sorghum bioactive compounds and probiotics, and some studies with CKD patients have highlighted the use of probiotic products with the strain Bifidobacterium longum for alleviation of inflammation and oxidative stress (Ogawa et al., 2012; Taki et al., 2005). The antioxidant effect has been demonstrated in healthy adults who consumed pasta ( 7 to 14 days) containing $30 \%$ of sorghum flour showed an increase in SOD activity and TAC (Khan et al., 2015).

Thus, the extruded sorghum cereal intake consumed with unfermented probiotic milk drink improved the oxidative stress and inflammation in patients with CKD.

\section{Conclusion}

The sorghum extruded from cultivar BRS 305 presented higher dietary fiber content, phenolic compounds and antioxidant activity than that showed by extruded maize morning cereal. These chemical characteristics are suitable to do this food part of the diet of patients with CKD since the intake of this cereal combined with probiotic milk with Bifidobacterium longum BL-G301 improved the inflammation and the oxidative stress in individuals with CKD on hemodialysis.

Supplementary data to this article can be found online at https:// doi.org/10.1016/j.foodres.2018.03.004.

\section{Conflict of interest}

The authors declare that they have no conflict of interest. 


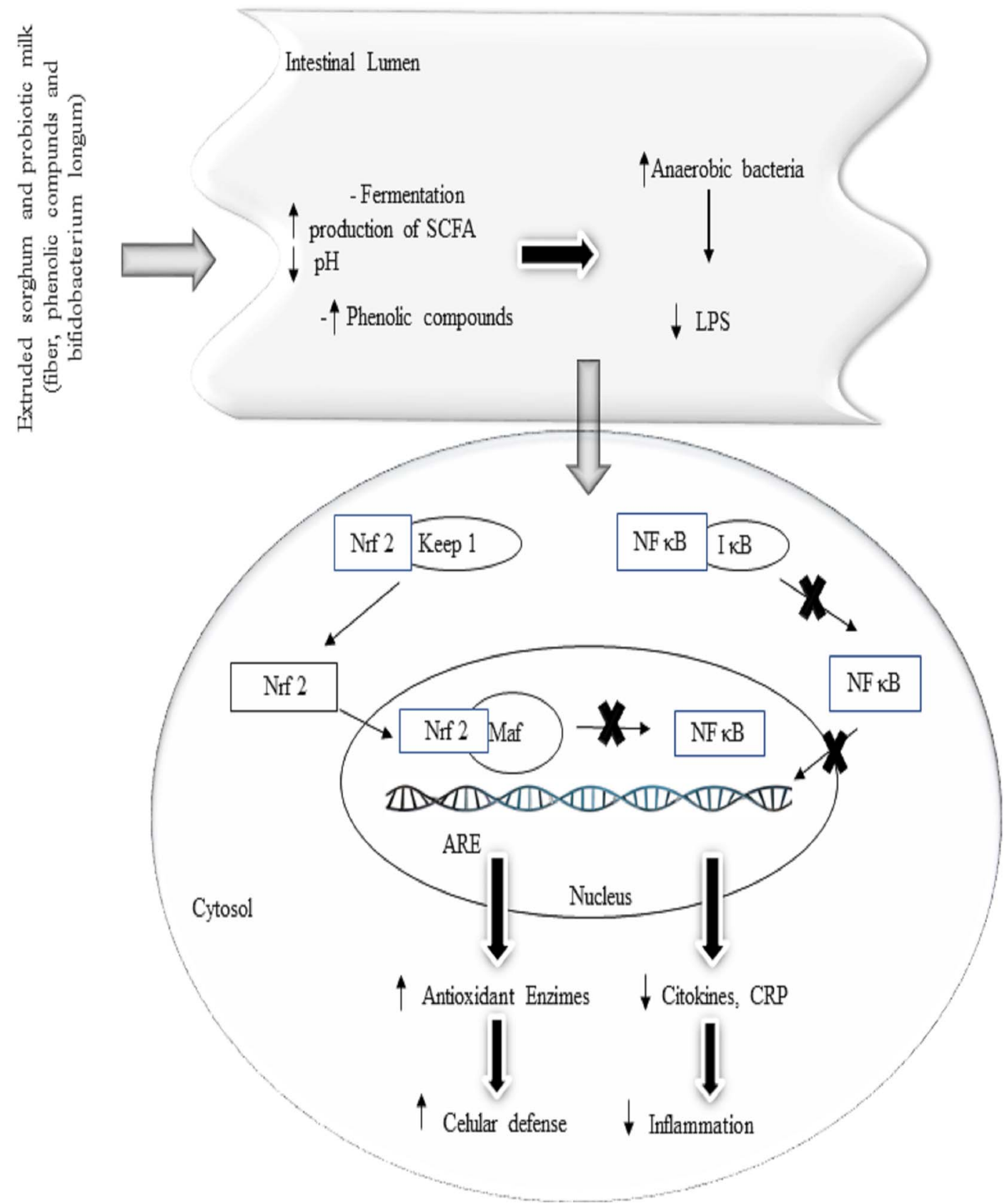

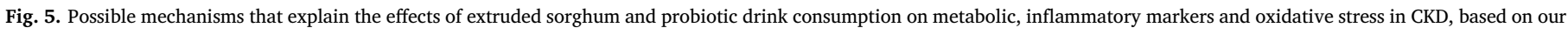

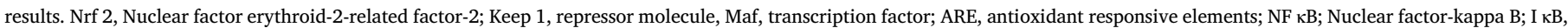
repressor molecule; CRP, C-Reactive Protein.

\section{Acknowledgements}

The authors thank the Foundation for Research Support of Minas Gerais (FAPEMIG CDS-APQ-01683-15, Brazil), Coordination for the Improvement of Higher Education Personnel (CAPES, Brazil), National Counsel of Technological and Scientific Development (CNPq, Brazil) and the Embrapa Maize and Sorghum (Brazil) for granting of financial support for undergraduate research and scholarships.

\section{References}

Anunciação, P. C., Cardoso, L.d. M., Gomes, J. V. P., Della Lucia, C. M., Carvalho, C. W. P., Galdeano, M. C., ... Pinheiro-Sant'Ana, H. M. (2017). Comparing sorghum and wheat whole grain breakfast cereals: Sensorial acceptance and bioactive compound content. Food Chemistry, 221, 984-989.

Anunciação, P. C., Cardoso, L. D. M., Queiroz, V. A. V., de Menezes, C. B., de Carvalho, C.
W. P., Pinheiro-SantAna, H. M., \& Alfenas, R. D. C. G. (2016). Consumption of a drink containing extruded sorghum reduces glycaemic response of the subsequent meal. European Journal of Nutrition, 1-7 (Springer Berlin Heidelberg).

ANVISA (2017). Alimentos Com Alegacoes de Propriedades Funcionais e ou de Saúde.

AOAC. Association of Official Analytical Chemists (2012). Official methods of analysis (19th ed.). (Gaithersburg).

Ashraf, R., \& Shah, N. P. (2011). Selective and differential enumerations of Lactobacillus delbrueckii subsp. bulgaricus, Streptococcus thermophilus, Lactobacillus acidophilus,

Lactobacillus casei and Bifidobacterium spp. in yoghurt-A review. International Journal of Food Microbiology, 149(3), 194-208.

Awika, J. M., Yang, L., Browning, J. D., \& Faraj, A. (2009). Comparative antioxidant, antiproliferative and phase II enzyme inducing potential of sorghum (Sorghum bicolor) varieties. LWT - Food Science and Technology, 42, 1041-1046.

Barreto, F. C., Oliveira, R. B., de Franco, A. T. B., Barreto, D. V., Pecoits-Filho, R., \& Massy, Z. A. (2014). The quest for a better understanding of chronic kidney. Jornal Brasileiro de Nefrologia, 36(2), 221-235.

Blois, M. S. (1958). Antioxidant determinations by the use of a stable free radical. Nature, 181(4617), 1199-1200.

Borges, N. A., Carmo, F. L., Stockler-Pinto, M. B., de Brito, J. S., Dolenga, C. J., Ferreira, D. 
C., ... Mafra, D. (2017). Probiotic supplementation in chronic kidney disease: A double-blind, randomized, placebo-controlled trial. Journal of Renal Nutrition, 1-9.

Bradford, M. M. (1976). A rapid and sensitive method for the quantitation of microgram quantities of protein utilizing the principle of protein-dye binding. 72, 248-254.

Buege, J. A., \& Aust, S. D. (1978). Microsomal lipid peroxidation. Methods in Enzymology, $52,302-310$.

Burdette, A., Garner, P. L., Mayer, E. P., Hargrove, J. L., Hartle, D. K., \& Greenspan, P. (2010). Anti-inflammatory activity of select sorghum (Sorghum bicolor) brans. Journal of Medicinal Food, 13, 879-887.

Burns, R. E. (1971). Method for estimation of tannin in grain Sorghum1. Agronomy Journal, 63(3), 511-512.

Cachofeiro, V., Goicochea, M., De Vinuesa, S. G., Oubiña, P., Lahera, V., \& Luño, J. (2008). Oxidative stress and inflammation, a link between chronic kidney disease and cardiovascular disease. Kidney International, 74(111), S4-S9.

Cardoso, L.d. M., Montini, T. A., Pinheiro, S. S., Pinheiro-SantAna, H. M., Martino, H. S. D., \& Moreira, A. V. B. (2014). Effects of processing with dry heat and wet heat on the antioxidant profile of sorghum. Food Chemistry, 152, 210-217.

Cardoso, L.d. M., Pinheiro, S. S., da Silva, L. L., de Menezes, C. B., de Carvalho, C. W. P., Tardin, F. D., ... Pinheiro-Sant'Ana, H. M. (2015). Tocochromanols and carotenoids in sorghum (Sorghum bicolor L.): Diversity and stability to the heat treatment. Food Chemistry, 172, 900-908.

Cardoso, L.d. M., Pinheiro, S. S., de Carvalho, C. W. P., Queiroz, V. A. V., de Menezes, C. B., Moreira, A. V. B., ... Pinheiro-Sant'Ana, H. M. (2015). Phenolic compounds profile in sorghum processed by extrusion cooking and dry heat in a conventional oven. Journal of Cereal Science, 65, 220-226.

Cardoso, L.d. M., Pinheiro, S. S., Martino, H. S. D., \& Pinheiro-Sant'Ana, H. M. (2017). Sorghum (Sorghum bicolor L.): Nutrients, bioactive compounds, and potential impact on human health. Critical Reviews in Food Science and Nutrition, 57(2), 372-390.

Castilla, P., Davalos, A., Teruel, J. L., Cerrato, F., Fernandez-Lucas, M., Merino, J. L., Lasuncion, M. A. (2008). Comparative effects of dietary supplementation with red grape juice and vitamin $\mathrm{E}$ on production of superoxide by circulating neutrophil NADPH oxidase in hemodialysis patients 1-3. The American Journal of Clinical Nutrition, 87, 1053-1061.

Chávez, D. W. H., Ascheri, J. L. R., Carvalho, C. W. P., Godoy, R. L. O., \& Pacheco, S. (2017). Sorghum and roasted coffee blends as a novel extruded product: Bioactive compounds and antioxidant capacity. Journal of Functional Foods, 29, 93-103.

Coombes, J. S., \& Fassett, R. G. (2012). Antioxidant therapy in hemodialysis patients: A systematic review. Kidney International, 81(3), 233-246.

Andrade, É. C. B., De Barros, A. M., Mello, V. D. S., \& Takase, I. (2004). Avaliação do teor de cobre e zinco em carnes cruas, processadas termicamente, resfriadas e congeladas no período de um mês. Ciência e Tecnologia de Alimentos, 24(3), 393-396.

Dykes, L., Seitz, L. M., Rooney, W. L., \& Rooney, L. W. (2009). Flavonoid composition of red sorghum genotypes. Food Chemistry, 116(1), 313-317.

Frary, C. D., \& Johnson, R. K. (2005). Energy. In L. K. MAHAN, \& S. K. ESCOTT-STUMP (Eds.). Alimentos, nutrição e dietoterapia (pp. 20-34). (São Paulo).

García-Mediavilla, V., Crespo, I., Collado, P. S., Esteller, A., Sánchez-Campos, S., Tuñón, M. J., \& González-Gallego, J. (2007). The anti-inflammatory flavones quercetin and kaempferol cause inhibition of inducible nitric oxide synthase, cyclooxygenase-2 and reactive C-protein, and down-regulation of the nuclear factor kappaB pathway in Chang liver cells. European Journal of Pharmacology, 557(2-3), 221-229.

Gionchetti, P., Rizzello, F., Morselli, C., Poggioli, G., Tambasco, R., Calabrese, C., ... Campieri, M. (2007). High-dose probiotics for the treatment of active pouchitis. Diseases of the Colon and Rectum, 50(12), 2075-2082.

Gomes, J. C. (1996). Análise de Alimentos. Viçosa: Universidade Federal de Viçosa.

Gomes, M. J. C., Infante, R. A., Silva, B. P., Moreira, M. E. C., Dias, D. M., Lopes, R. C. S. O., ... Martino, H. S. D. (2017). Sorghum extrusion process combined with biofortified sweet potato contributed for high iron bioavailability in Wistar rats. Journal of Cereal Science, 75, 213-219.

Hill, N. R., Fatoba, S. T., Oke, J. L., Hirst, J. A., O'Callaghan, C. A., Lasserson, D. S., \& Hobbs, F. D. R. (2016). Global prevalence of chronic kidney disease - A systematic review and meta-analysis. PLOS ONE, 11(7), e0158765.

Jellife, D. B. (1968). Evaluación del estado de nutrición de la comunidad. Ginebra: Organización Mundial de La Salud.

Kallapura, G., Pumford, N. R., Hernandez-velasco, X., \& Hargis, B. M. (2014). Mechanisms involved in lipopolysaccharide derived ROS and RNS oxidative stress and septic shock. Journal of Microbiology Research and Reviews, 2(1), 6-11.

Khan, I., Yousif, A. M., Johnson, S. K., \& Gamlath, S. (2015). Acute effect of sorghum flour-containing pasta on plasma total polyphenols, antioxidant capacity and oxidative stress markers in healthy subjects: A randomised controlled trial. Clinical Nutrition, 34(3), 415-421.

Kim, J., Cha, Y. N., \& Surh, Y. J. (2010). A protective role of nuclear factor-erythroid 2related factor-2 (Nrf2) in inflammatory disorders. Mutation Research, Fundamental and Molecular Mechanisms of Mutagenesis, 690(1-2), 12-23.

Lemos, J. R. N., Alencastro, M. G., de Konrath, A. V., Cargnin, M., \& Manfro, R. C. (2012). Flaxseed oil supplementation decreases C-reactive protein levels in chronic hemodialysis patients. Nutrition Research, 32(12), 921-927.

Li, H., Jiao, M., Chen, J., \& Liang, Y. (2010). Roles of zinc and copper in modulating the oxidative refolding of bovine copper, zinc superoxide dismutase. Acta Biochimica et Biophysica Sinica, 42(3), 183-194.

Lipschitz, D. (1994). Screening for nutritional status in the elderly. Primary Care, 21
$55-67$.

Llopart, E. E., Drago, S. R., De Greef, D. M., Torres, R. L., \& González, R. J. (2013). Effects of extrusion conditions on physical and nutritional properties of extruded whole grain red sorghum (Sorghum spp.). International Journal of Food Sciences and Nutrition, 7486(1), 1-8.

Martino, H. S. D., Tomaz, P. A., Moraes, É. A., Conceição, L. L., da Oliveira, D., da S. Queiroz, V. A. V., ... Ribeiro, S. M. R. (2012). Chemical characterization and size distribution of sorghum genotypes for human consumption. Revista do Instituto Adolfo Lutz, 71(2), 337-344.

Maxon, E. D., \& Rooney, L. W. (1972). Evaluation of methods for tannin analysis in sorghum grain. Cereal Chemistry, 49, 719-729.

Medicine, I. of (2002). Energy. Dietary reference intakes - Energy, carbohydrate, fiber, fat, fatty acids, cholesterol, protein, and amino acids (pp. 7.1-7.69). Washington: The National Academy Press.

Moraes, E. A., Marineli, R.d. S., Lenquiste, S. A., Queiroz, V. A. V., Camargo, R. L., Borck, P. C., ... Marostica Jynior, M. R. (2017). Whole sorghum flour improves glucose tolerance, insulin resistance and preserved pancreatic islets function in obesity dietinduced rats. Journal of Functional Foods, 1-11.

Moraes, É. A., Natal, D. I. G., Queiroz, V. A. V., Schaffert, R. E., Cecon, P. R., de Paula, S. O., ... Martino, H. S. D. (2012). Sorghum genotype may reduce low-grade inflammatory response and oxidative stress and maintains jejunum morphology of rats fed a hyperlipidic diet. Food Research International, 49(1), 553-559.

Odamaki, T., Sugahara, H., Yonezawa, S., Yaeshima, T., Iwatsuki, K., Tanabe, S. ... Xiao, J. (2012). Effect of the oral intake of yogurt containing Bifidobacterium longum BB536 on the cell numbers of enterotoxigenic Bacteroides fragilis in microbiota. Anaerobe, 18(1), 14-18.

Ogawa, T., Shimada, M., Nagano, N., Ito, K., Ando, T., Shimomura, Y., ... Otsuka, K. (2012). Oral administration of Bifidobacterium longum in a gastro-resistant seamless capsule decreases serum phosphate levels in patients receiving haemodialysis. Clinical Kidney Journal, 5(4), 373-374.

Oliveira, D., Vidal, L., Ares, G., Walter, E. H. M., Rosenthal, A., \& Deliza, R. (2017). Sensory, microbiological and physicochemical screening of probiotic cultures for the development of non-fermented probiotic milk. LWT - Food Science and Technology, 79, 234-241.

Prince, M. L., Van Scoyoc, S., \& Butler, L. G. (1978). A critical evaluation of the vanillin reaction as an assay for tannin in sorghum grain. Journal of Agricultural and Food Chemistry, 25(5), 1214-1218.

Reid, G. (2008). Probiotics and prebiotics - Progress and challenges. International Dairy Journal, 18(10-11), 969-975.

Riella, C. M., \& Martins, C. (2001). Nutrição e o Rim. Rio de Janeiro: Guanabara Koogan.

Rossi, M., Johnson, D. W., Morrison, M., Pascoe, E. M., Coombes, J. S., Forbes, J. M., .. Campbell, K. L. (2016). Synbiotics easing renal failure by improving gut microbiology (SYNERGY): A randomized trial. Clinical Journal of the American Society of Nephrology, 11(2), 223-231.

Rossi, M. M., Klein, K., Johnson, D. W., \& Campbell, K. L. (2012). Pre-, pro-, and synbiotics: Do they have a role in reducing uremic toxins? A systematic review and metaanalysis. International Journal of Nephrology, 2012, 1-20.

Saldanha, J. F., Leal, V. O., Rizzetto, F., Grimmer, G. H., Ribeiro-Alves, M., Daleprane, J. B., ... Mafra, D. (2016). Effects of resveratrol supplementation in Nrf2 and NF-kB expressions in nondialyzed chronic kidney disease patients: A randomized, doubleblind, placebo-controlled, crossover clinical trial. Journal of Renal Nutrition, 26(6), 401-406.

Seifried, H. E., Anderson, D. E., Fisher, E. I., \& Milner, J. A. (2007). A review of the interaction among dietary antioxidants and reactive oxygen species. Journal of Nutritional Biochemistry, 18(9), 567-579.

Sesso, R. C., Lopes, A. A., Thomé, F. S., Lugon, J. R., \& Martins, C. T. (2016). Inquérito Brasileiro de Diálise Crônica 2014. Jornal Brasileiro de Nefrologia, 38(1), 54-61.

Shih, P.-H., Yeh, C.-T., \& Yen, G.-C. (2007). Anthocyanins induce the activation of phase II enzymes through the antioxidant response element pathway against oxidative stressinduced apoptosis. Journal of Agricultural and Food Chemistry, 55(23), 9427-9435.

Singleton, V. L., Orthofer, R., \& Lamuela-Raventós, R. M. (1999). Analysis of total phenol and other oxidation substrates and antioxidants by means of Folin-Ciocalteu reagent. Methods in Enzymology, 299, 152-177.

Taki, K., Takaiama, F., \& Niwa, T. (2005). Beneficial effects of Bifidobacteria in a gas troresistant seamless capsule on hyperhomocysteinemia in hemodialysis patients. Journal of Renal Nutrition, 15(1), 77-80.

Trompette, A., Gollwitzer, E. S., Yadava, K., Sichelstiel, A. K., Sprenger, N., Ngom-Bru, C., .. Marsland, B. J. (2014). Gut microbiota metabolism of dietary fiber influences allergic airway disease and hematopoiesis. Nature Medicine, 20(2), 159-166.

Vattem, D. A., \& Shetty, K. (2005). Biological functionality of ellagic acid: A review. Journal of Food Biochemistry, 29(3), 234-266.

WHO. World Health Organization (1997). Obesity: Preventing and managing the global epidemic. Report of WHO, Consultation on Obesity. Genebra.

Whorwell, P. J., Altringer, L., Morel, J., Bond, Y., Charbonneau, D., O'Mahony, L., ... Quigley, E. M. M. (2006). Efficacy of an encapsulated probiotic Bifidobacterium in fantis 35624 in women with irritable bowel syndrome. American Journal of Gastroenterology, 101(7), 1581-1590.

Yang, L., Allred, K. F., \& Geera, B. (2012). Sorghum phenolics demonstrate estrogenic action and induce apoptosis in nonmalignant colonocytes. Nutrition and Cancer, 64(3), 419-427. 